\title{
Experimental study of the processes of aerosol production for technical oil cleanup
}

\author{
Gennadiy Medvedev ${ }^{1, *}$ \\ ${ }^{1}$ National Research Tomsk Polytechnic University, 634050 Tomsk, Russia
}

\begin{abstract}
From the experimental study of mechanism of fine mist formation in oil-flooded screw compressor it has been drawn the conclusion on evaporation of fine aerosol of mineral oil that has been obtained in two ways: on the basis of oil spray with mechanical burner and on the basis of volume condensation of oil vapour in air. The given paper presents experimental facility for the production of mineral oil aerosol and also comparison of the experimentation results with calculations.
\end{abstract}

\section{Introduction}

Mist formation in steam gas flow in most cases turns up to be an undesirable phenomena (sulfuric mist, chimney spouted smoke, etc.), but in some cases it is essential to create mist with special characteristics [1,2], for example, in development of facilities for testing gas cleaning apparatus or for some other scientific or practical purposes.

\section{Experimental facility scheme and its specification}

In order to produce mineral oil aerosols the experimental facility has been developed; its scheme is represented in Fig.1. The facility comprises such basic elements as a vapour source, an oil separator and an air control unit.

In the evaporator vessel (1) which is hermetically sealed with a cover (2) the used mineral oil (7) heating with the help of the controllable electric heater (8) is filled. The oil temperature is controlled with the thermoelectric transducer (6) canned with the thermocouple cover (5). In the evaporator the mineral oil vapours are mixed with the air stream coming from the receiver (14) per the air supply tube (4), thus forming here air mist. Out of the evaporator the oil aerosol is delivered into the oil separator where the mineral oil (12) tramped with the special filtering element (11) congregates in the lower part of the filter shell (9). Thereafter the air is let out of the oil separator throughout the pouring hole of the cover (10) into the atmosphere. The output oil concentration is varied on account of air consumption changes and the load upon the evaporator heater. The air consumption in the facility is controlled with the help of the gearbox (15) and the air valve (16). At high concentrations the growth of mineral oil particles before the oil separator may occur and the

\footnotetext{
* Corresponding author: ggm@tpu.ru
} 
removal efficiency will increase. The air control unit includes the air compressor (13) which pressurizes air to the receiver (14) to the necessary level of pressure.

The operating result of the separation facility is refined from heavy fractions and disperse impurities of the mineral oil (12).

The temperature in the facility elements has been measured with the copper-toconstantan thermocouples. As a secondary instrument millivoltmeter has been used.

To determine the air consumption the pre-gradable float variable-area flowmeter has been used.

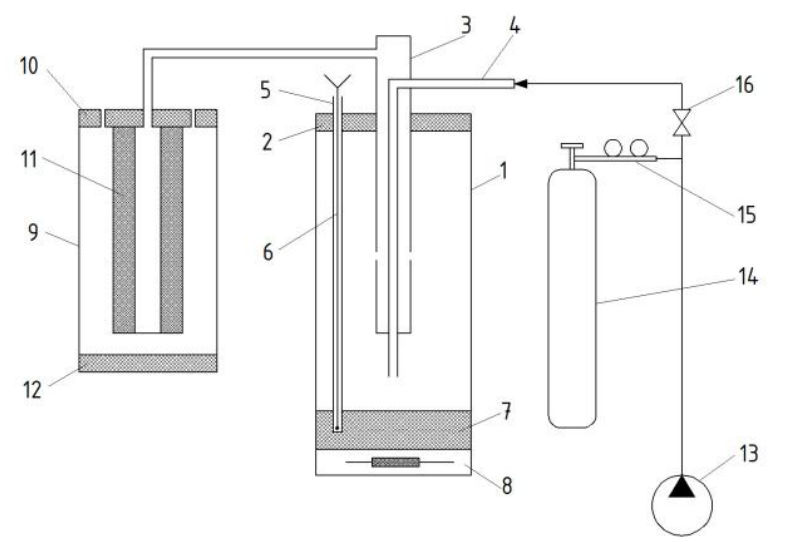

Fig.1. The scheme of the separation facility for used mineral oil cleanup: 1 - evaporator vessel, 2 - cover, 3 - aerosol outlet nozzle, 4 - air supply tube, 5 - thermocouple cover, 6 thermocouple, 7 - used oil, 8 - heater, 9 - filter shell, 10 - cover, 11 - filtering element, 12 - refined oil, 13 - compressor, 14 - receiver, 15 - gearbox, 16 - control air valve.

\section{The study of heat transfer in the oil evaporator and aerosol production}

The study of heat transfer included measurements of oil temperature, air temperature on entry of the evaporator and air temperature on exit from it. During experimentation the moments of oil mist occurrence were also recorded.

Data on heat transfer over the air were obtained with the purpose of evaluation of particular parameters of heat balance of air - vacuum oil hot surface interaction. During the first stage there were conducted evaluations of such parameters: oil surface radiation heat transfer $\mathrm{Q}_{\mathrm{p}}$, evaporation ingredient $\mathrm{Q}_{\mathrm{i}}$ which was estimated on the quantity of formed aerosol, surface-to-air convection component $\mathrm{Q}_{\mathrm{k}}$. With the values of oil temperature $\mathrm{T}_{3}=220^{\circ} \mathrm{C}$, air consumption $\mathrm{G}=0.0001 \mathrm{~m}^{3} / \mathrm{s}$, heat transfer coefficient $\alpha=10 \mathrm{~W} /\left(\mathrm{m}^{2} \cdot \mathrm{K}\right)$ the following data were received: $\mathrm{Q}_{\mathrm{p}}=23 \mathrm{~W}, \mathrm{Q}_{\mathrm{i}}=8.9 \mathrm{~W}, \mathrm{Q}_{\mathrm{k}}=15.7 \mathrm{~W}$ and the sum $\mathrm{Q}_{\mathrm{s}}=47.6 \mathrm{~W}$. Considering that the released by heater heat quantity is equal to $500 \mathrm{~W}$, the developed experimental facility has low efficiency.

During the second stage there was an attempt to clear up the question of mechanism of convection heat transfer between the oil surface and air stream. For this reason we considered the model that is schematically shown in Fig.2. 


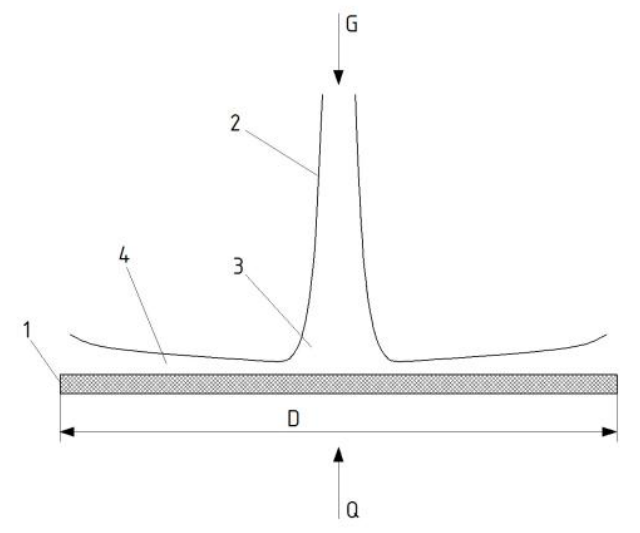

Fig.2. The scheme to the calculation of heat transfer between the air stream and vacuum oil layer.

The oil layer 1 on the surface in diameter D is blown over the nozzle 2 by the air flow with consumption G. In the plan of heat interaction of flow with the oil surface it is required to divide the flow region into region 3 where the turn of air flow takes place and its direct straight leakage on surface occurs (as in flow-around of «stagnation point») and region 4 where surface flow with a kind of a wall jet takes place which velocity can be explained by a well-known «Schlichting velocity profile».

In this particular case the region 3 is much less than the region 4 in magnitude of the surface. Thus, the observed diameter of a dimple of the oil surface amounts to approximately $8 \mathrm{~mm}$ in diameter of muzzle equal to $5 \mathrm{~mm}$ whereas the diameter of bottom totals $100 \mathrm{~mm}$. Therefore at a first approximation when analyzing convective heat transfer we assumed the use of the so called channeling flow relations. As it was impossible to directly determine the heat transfer coefficient it was suggested to use model laws of heat transfer for calculation of total heat flux adding to air.

To calculate local heat transfer in channeling flows the relationship [1] was taken

$$
\mathrm{St}_{\mathrm{m}}=0.0287 \operatorname{Re}_{x}^{-0,2} \operatorname{Pr}^{-0.6}\left(\cos \varphi_{0}\right)^{-0.6},
$$

where $\mathrm{St}_{\mathrm{m}}=\alpha /\left(\rho c_{p} u_{m x}\right)-$ Stanton number; $u_{m x}$ - maximum longitudinal velocity in a wall jet; $\rho, c_{p}-$ gas density and heat capacitance; $\alpha-$ heat transfer coefficient; $\operatorname{Re}_{x}=u_{m x} x / v$ - Reynold's number; $v$ - air kinematic viscosity; $\operatorname{Pr}$ - air Prandtl number; $\varphi_{0}$ - angle between axial and и tangential components of velocities скоростей on wall (swirl angle $\varphi_{0}=0$ ).

It is essential to take into account that the law of velocity variation $u_{m}$ in swirl flows is different. For our particular case the law [3] was taken

$$
u_{m}=u_{0} c \frac{d_{c}}{r}
$$

Here $u_{0}$ - velocity of gas outflow; $d_{c}$ - nozzle diameter; $r$ - radial coordinate counting off from nozzle axe and oil surface; $c$ - constant.

In accordance with the formula (1) we calculated the local coefficient of heat transfer radially the oil surface, then we calculated the local heat transfer and by means of surface integration - full heat flux. 
The Fig.3 presents the results of calculations with the use of different values of constants in the formula (1) in comparison with the experimental data.

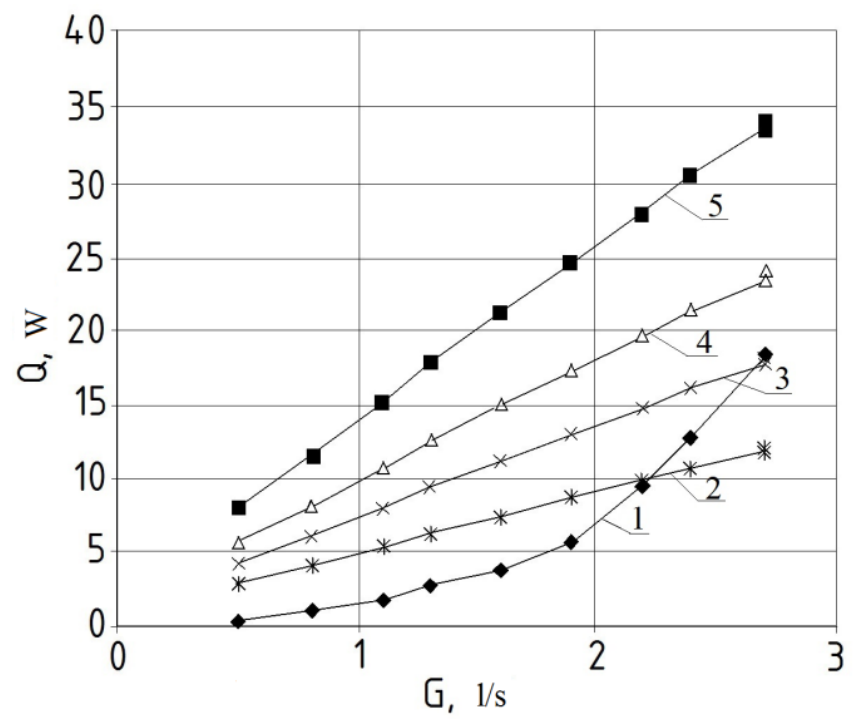

Fig.3. The dependence of convective heat flow on air consumption: curved lines: 1 experimentation; $2-\mathrm{A}=0.01 ; 3-\mathrm{A}=0.015 ; 4-\mathrm{A}=0.02 ; 5-\mathrm{A}=0.0287$.

As it can be seen in the general case the calculation differs from experimentation, but closer values can be received with reduction of constant coefficient in the formula (1).

\section{References}

1. S.A. Shutov, A.R. Dorokhov, K.P. Kutzenogi, S.E. Paschenko, Mekhanizm obrazovaniya melkodispersnogo tumana $v$ maslozapolnennym vintovogo kompressora (1983) [in Russian]

2. S.A. Shutov, A.R. Dorokhov, K.P. Kutzenogi, S.E. Paschenko, Eksperimental'nyye issledovaniya ob"yemnoy kondensatsii parov nefteproduktov. Issledovaniye dispersnykh sistem $v$ energeticheskikh khimicheskikh protsessov (1982) [in Russian]

3. E.P. Dybin, A.I. Mazur, Konvektivnyy teploobmen pri strunnoy obtekaniya tela (1982) [in Russian]

4. S.S. Kutateladze, E.P. Volchkov, V.I. Terekhov, Aerodinamika i teplomassoobmen v ogranichennykh vikhrevykh potokakh (1987) [in Russian] 